\title{
A ESCURIDÃO E A MADRESSILVA: MANIFESTAÇÕES LÍRICAS NA NARRATIVA DE QUENTIN COMPSON EM $O$ SOM E A FÚRIA, DE WILLIAM FAULKNER
}

\section{THE DARKNESS AND THE HONEYSUCKLE: LYRICAL MANIFESTATIONS IN QUENTIN COMPSON' S NARRATIVE IN THE SOUND AND THE FURY, BY WILLIAM FAULKNER}

\author{
Claudimar Pereira da Silva ${ }^{1}$
}

Recebido em: 30 jun. 2019.

Aceito em: 22 dez. 2019

DOI 10.26512/aguaviva.v5i1.24940

RESUMO: O presente artigo objetiva a análise da narrativa de Quentin Compson, no romance O som e a fúria (2004), do escritor americano William Faulkner, no que tange às teorias da narrativa poética propostas por Jean-Yves Tadié (1978) e Ralph Freedman (1971). Assim, pretende-se analisar o modo como estrutura-se a voz lírica de Quentin, por meio das técnicas de fluxo de consciência e monólogo interior, pela verticalização sintática, pela projeção lírica do narrador nos espaços e pelo recurso às imagens, símbolos e metáforas, articuladas à diegese.

Palavras-chave: Narrador. Narrativa poética. Monólogo interior. Fluxo de consciência. William Faulkner.

\begin{abstract}
This article aims to analyze the narrative of Quentin Compson, in the novel The Sound and the Fury (2004), by the American writer William Faulkner, regarding the poetic narrative theories proposed by Jean-Yves Tadié (1978) and Ralph Freedman (1971). Thus, we intend to analyze the way in which Quentin's lyrical voice is structured, through the techniques of interior monologue and stream of consciousness, by the syntactic verticalization, the lyrical projection of the narrator in spaces and the use of images, symbols and metaphors, articulated to the diegesis.
\end{abstract}

Keywords: Narrator. Poetic narrative. Interior monologue. Stream of consciousness. William Faulkner.

\footnotetext{
${ }^{1}$ Doutorando pelo Programa de Pós-Graduação em Estudos Literários da Universidade Estadual Paulista "Júlio de Mesquita Filho" (UNESP), campus de Araraquara. Atualmente desenvolve pesquisa sobre as representações das masculinidades na obra de William Faulkner. Obteve o título de mestre pela mesma instituição. Licenciado e bacharel em Letras nas áreas de Português-Inglês pela Universidade Estadual Paulista (UNESP). E-mail: claudimarsilva84@gmail.com
} 


\section{INTRODUÇÃO}

No ano de 1956, o escritor estadunidense William Faulkner, em entrevista à revista literária francesa Paris Review (2011), fez uma afirmação curiosa: "Sou um poeta fracassado. Talvez todo romancista queira antes escrever poesia, depois descubra que não pode, e aí experimenta o conto, que é a forma mais exigente depois da poesia" (STEIN, 2011, p. 10, grifo nosso). Partindo dessa afirmativa, torna-se patente que o poético, para Faulkner, manifestavase como objeto de busca e desejo, e era sublimado posteriormente, de modo rigoroso, em outras formas literárias. Desse modo, o escritor optou pelo gênero narrativo no intuito de representar a geografia humana da região sul dos Estados Unidos, sedimentada na cartografia imaginária do condado de Yoknapatawpha ${ }^{2}$ (VOLPE, 1967, p. 23).

Na realidade, durante um breve período de sua carreira, Faulkner investigou a métrica lírica: seu primeiro livro, The Marble Faun, publicado em 1924, consiste em uma coletânea de poemas influenciados por W. B. Yeats e T.S Eliot, e pela dicção decadentista fin-de-siécle, ainda em voga à época (BLEIKASTEN, 1990, p. 3-4). Ainda assim, a postura de Faulkner em relação ao tema permanecia ambígua. Em 1957, em suas palestras como escritor visitante na Universidade da Virginia, Faulkner relativizou a importância de elementos poéticos na fatura final de sua obra:

Eu acho que o escritor está preocupado primeiramente em narrar histórias de pessoas em conflito consigo mesmas e com os outros, com o meio em que vivem, e, não utilizando deliberadamente o método lírico, ele usa qualquer técnica que lhe pareça a mais apropriada para contar o que está tentando contar, da maneira mais dramática e apaixonada possível. Pode lhe parecer melhor usar um método lírico ou talvez seja o resultado - de sua própria agonia e angústia, para que se possa afirmar que o que ele quer narrar se torna lírico. ${ }^{3}$

\footnotetext{
${ }^{2}$ Palavra de origem indígena, da tribo dos Chickasaw, formada pela junção dos termos yocona (terra) e petowpha (divisão), ou seja "terra dividida". Alguns críticos definem a etimologia da palavra como significando "água corre devagar sobre terra plana" (GRANGEIRO, 2011, p. 12-3; OLIVEIRA, 2016, p. 20).

3 "I think the writer is concerned first in telling about people, people in conflict with themselves and with others, with their environment, and he uses whatever method seems to him the best to tell what he is trying to tell in the most dramatic and passionate way, that he is not trying to use a lyrical method deliberately. It may seem to him best to use a lyrical method or maybe the result of - of his own agony and anguish to say what he wants to say becomes lyrical." Disponível em: <http://faulkner.lib.virginia.edu/display/wfaudio06_1\#wfaudio06_1.22>. Acesso em 22/09/2018.
} 
Mais do que o despistamento autoral de alguns escritores, há que se analisar a materialidade literária a partir de seus próprios componentes. Nesse sentido, é interessante notar o quanto a falácia de Faulkner discursiviza a mecânica da narrativa poética, isto é, um tipo de narrativa que não se ocupa apenas com a objetividade de enredo, ações e eventos, mas que mobiliza expedientes líricos que possibilitam a representação subjetiva de narradores e personagens (FREEDMAN, 1971, p. 1).

Volpe (1967) assinala a predominância da narrativa poética no corpus faulkneriano: “[...] Como um poeta, Faulkner está se comunicando primeiramente em um nível emocional. Suas técnicas, monólogos interiores, símbolos, imagens [...] tudo contribui para a criação e comunicação de sentimento"4 (VOLPE, 1967, p. 96, tradução nossa). Assim, a narrativa de Faulkner, além de agregar o movimento escorregadio dos tempos, a pluralidade de vozes e perspectivas, e as linguagens resultantes de subjetividades fragmentadas, também materializase em ritmos, sonoridades e imagens, que podem ser analisadas por meio das teorias da narrativa poética de Jean-Yves Tadié (1978) e Ralph Freedman (1971).

Respaldando Volpe, Azevedo (2006), por sua vez, reitera a manifestação da poeticidade na obra de Faulkner, no sentido de que o autor "[...] reflecte sobre a importância e o poder da palavra [...] Estas são convocadas para logo serem libertas dos seus sentidos habituais, sem que [...] o autor alguma vez se debruce [...] sobre o acto criativo da sua própria escrita" (AZEVEDO, 2006, p. 94). O trecho a seguir, retirado do fluxo de consciência de Quentin Compson, do romance $O$ som e a fúria (2004), exemplifica o teor lírico da narrativa faulkneriana:

Seguimos em frente. A rua estava tranquila, quase ninguém a nossa volta $o$ odor de madressilva se misturando a tudo Ela teria me dito para não deixar ficar sentado na escada ouvindo a porta dela entardecer batendo Benjy ainda chorando Jantar ela teria de descer então o odor de madressilva se misturando a tudo Chegamos à esquina (FAULKNER, 2004, p. 124-5).

No trecho destacado, Quentin caminha pelas ruas de Boston, logo pela manhã. Por meio do fluxo de consciência, o narrador registra sua percepção espacial ("A rua estava tranquila,

\footnotetext{
4 "Like a poet, Faulkner is communicating primarily on an emotional level. His techniques, interior monologues, symbols, images $[\ldots]$ all contribute to the creation and communication of feeling" (VOLPE, 1967, p. 96).
} 
quase ninguém a nossa volta"), e em seguida a narrativa esboroa-se em uma sequência desordenada de imagens ("porta", madressilva", "entardecer") e sinestesias (“ouvindo a porta bater", "o odor de madressilva"), incrustadas no tecido memorialístico, constituindo-se como fragmentos sintáticos dentro da própria fragmentação do fluxo de consciência da personagem (SILVA, 2019, p. 41).

Em Le recit poetique, Jean-Yves Tadié (1978) define a narrativa poética como gênero cujos dispositivos estruturais "[...] remetem ao poema: há nela um conflito constante entre a função referencial, com seu papel de evocação e representação, e a função poética, que chama a atenção para a própria forma da mensagem" (TADIÉ, 1978, p. 3). Assim, ela caracteriza-se por fusionar a objetividade própria da narrativa à figuratividade da poesia, através da mobilização de "[...] um sistema de ecos, de retomadas, de contrastes [...] das assonâncias, das aliterações, das rimas [...]. [...] os paralelismos semânticos, as confrontações entre unidades de sentido que podem ser paisagens ou personagens [...]" (TADIÉ, 1978, p. 03).

Em abordagem análoga a de Tadié, Ralph Freedman (1971) sugere que a narrativa poética almeja o efeito estético do poema. Desse modo, “[...] o romance poético desloca a atenção do leitor de homens e eventos para a forma" (FREEDMAN, 1971, p. 01), possibilitando à estrutura narrativa saltar a um primeiro plano, em detrimento de seu conteúdo. Além disso, para Freedman, a narrativa lírica caracteriza-se pela representação de um eu poético, que projeta-se liricamente nos espaços e objetos (FREEDMAN, 1971, p. 2).

Se a narrativa poética define-se pela forma na qual é veiculada, pode-se considerar que o romance $O$ som e a fúria (2004), publicado em 1929, configura-se como uma das obras mais poéticas do corpus faulkneriano. Para Silva (2019), a poeticidade deste romance advém de sua estrutura fragmentada, formada por “[...] puzzles de linguagem, estratos temporais embaralhados, fragmentação subjetiva, ritmo, imagens e símbolos, constituindo assim uma gramática poético-esquizoide, voltada para si mesma e sua própria construção" (SILVA, 2019, p. 44).

O som e a fúria narra a saga da dinastia Compson, uma família de passado aristocrata da região sul dos Estados Unidos que, no final da década de 1920, atinge o ápice de seu processo de decomposição moral e econômica. A família é formada pelos pais Jason Lycurgus e Caroline

\footnotetext{
5 Todas as traduções de Jean-Yves Tadié feitas do francês foram disponibilizadas pela profa. Dra. Ana Luiza Camarani, do Departamento de Letras Modernas da UNESP, campus de Araraquara.
} 
Bascomb, além de quatro filhos: Quentin, narrador do corpus deste artigo, além de Caddy (única mulher entre os irmãos), Jason e Benjy, o filho mais novo e deficiente mental (FAULKNER, 2004, p. 313).

Mobilizando as técnicas de monólogo interior e fluxo de consciência, $O$ som e a fúria fratura-se em quatro partes, calcadas em datas distintas, e cada uma delas é narrada por um dos irmãos, no caso Benjy, Quentin e Jason, nessa ordem, a partir de sintaxe e semântica diversas. $\mathrm{Na}$ quarta parte do romance, há a presença de um narrador onisciente, que ocupa-se em representar o cotidiano de Dilsey, a empregada negra dos Compson (GENETTE, 1979).

Nesse sentido, a forma polifônica de $O$ som e a fúria, esfacelada em quatro partes, sendo as duas primeiras enxertadas com grandes experimentações de linguagem, sedimenta-se como um corpo poroso, poético e metanarrativo, no qual os sons lentos e estáticos da desagregação familiar e, por conseguinte, de toda a conjuntura histórico-social do sul dos Estados Unidos, encontram sua base de sustentação. Para Bleikasten (1990), “[...] o fracasso informa o próprio padrão do romance, já que suas quatro seções representam tentativas vãs de contar a história"6 (BLEIKASTEN, 1990, p. 45, tradução nossa).

Neste emaranhado de linguagem que é $O$ som e a fúria, Quentin Compson figura como a voz mais lírica deste romance. Quentin é um rapaz sensível e intelectualizado, obcecado pela morte e por desejos incestuosos em relação à irmã Caddy, e que comete suicídio ao anoitecer do dia 02 de junho de 1910, afogando-se nas águas de um rio. Brooks (1990) detecta resíduos poéticos fin-de-siècle na narrativa de Quentin, cuja forma é “[...] essencialmente decadente: sensível, porém neurótica e sem esperança"7 (BROOKS, 1990, p. 328, tradução nossa).

Ressaltemos ainda a importância de Caddy na economia narrativa de $O$ som e a fúria, já que os monólogos interiores de Quentin centralizam-se de maneira doentia em sua figura. Durante a adolescência, Caddy dá vazão a seus impulsos sexuais como válvula de escape às demandas familiares (FAULKNER, 2004, p. 66-7). A personagem não possui voz individualizada no escopo do romance, e é narrada a partir da consciência de Benjy, Quentin e Jason, cada qual obcecado por ela à sua maneira.

\footnotetext{
6 " [...] failure informs the very pattern of the novel, since its four sections represent so many vain attempts at getting the story told" (BLEIKASTEN, 1990, p. 45).

7 “[...] [it] is essentially decadent: sensitive but neurotic and hopeless” (BROOKS, 1990, p. 328).
} 
Assim, este artigo objetiva a análise da narrativa poética no enunciado de Quentin Compson, a partir dos pressupostos teóricos de Jean-Yves Tadié (1978) e Ralph Freedman (1971). Pretende-se analisar o discurso poético do narrador a partir da deformação textual, da mobilização de imagens, e pela projeção lírica da subjetividade de Quentin nos espaços e objetos.

\section{A instabilidade do narrar}

A parte de $O$ som e a fúria dedicada à voz narrativa de Quentin inicia-se com a focalização do narrador direcionada à "[...] sombra do caixilho na cortina", que aparece entre sete e oito horas da manhã (FAULKNER, 2004, p. 73). Quentin está em seu quarto no alojamento para estudantes de Harvard. Ao prestar atenção no som do tique-taque de seu relógio, potencializado pelo silêncio da manhã, a personagem narra um dos trechos mais famosos deste romance, no qual relembra o dia em que o pai lhe deu o relógio:

Era o relógio de meu avô, e quando o ganhei de meu pai ele disse Estou the dando o mausoléu de toda esperança e todo desejo; é extremamente provável que você o use para lograr o reducto absurdum de toda experiência humana, que será tão pouco adaptado às suas necessidades individuais quanto foi às dele e às do pai dele. Dou-lhe este relógio não para que você se lembre do tempo, mas para que você possa esquecê-lo por um momento de vez em quando e não gaste todo seu fôlego tentando conquistá-lo. Porque jamais se ganha batalha alguma, ele disse. Nenhuma batalha sequer é lutada. O campo revela ao homem apenas sua própria loucura e desespero, e a vitória é uma ilusão de filósofos e néscios (FAULKNER, 2004, p. 73).

Durante este dia 02 de junho de 1910, a dicção proverbial do pai de Quentin ressoará em sua consciência, trazida pelos mecanismos da memória, como as batidas sonoras de um sino que permanecem no ar "[...] mais sentidas do que ouvidas" (FAULKNER, 2004, p. 76): "O pai falava no excesso de especulações a respeito da posição de ponteiros sobre um mostrador arbitrário que é sintoma de funcionamento mental. Excremento dizia o pai é como suor. E eu dizendo está bem. Querendo saber. Fique querendo” (FAULKNER, 2004, p. 74).

Quentin segue atento aos sons do quarto: "Ele estava encostado na caixa de colarinhos, e eu o escutava deitado. [...] Ouvi do outro lado da parede a cama de Shreve e depois os chinelos dele se arrastando pelo chão" (FAULKNER, 2004, p. 74). Nesta primeira cena, a dimensão lírica da narrativa realiza-se no paralelismo semântico entre o estado de introspecção de Quentin 
e o espaço no qual ele está inserido. Desse modo, o quarto, como locus que remete à intimidade, delimita-se como a representação espacializada do monólogo interior de Quentin, corroborando Bachelard (1993), para quem, “A casa, o quarto, o sótão onde ficamos sozinhos dão os quadros de um devaneio interminável” (BACHELARD, 1993, p. 34). Neste espaço materializado, que é também o espaço de sua consciência, Quentin deixa a mente fluir, e pode relembrar episódios da história familiar e repassar os planos para este dia.

No entanto, Quentin não suporta ouvir os estalidos do relógio: "Fui até a cômoda e peguei o relógio [...]. Quebrei o vidro na quina do móvel e aparei os cacos na mão e coloqueios no cinzeiro e arranquei os ponteiros [...]. O tique-taque não parou" (FAULKNER, 2004, p. 77). Mais um paralelismo semântico revela-se: quebrar o relógio, isto é, dar uma ausência de forma ao objeto opera como metáfora para os planos de suicídio do narrador, quando Quentin, um indivíduo com forma, mergulhará no fluxo barrento e amorfo do rio, desejando a dissolução. Segundo Volpe (1967), o desejo pela morte advém do descompasso no mundo interior de Quentin, que é "[...] emocionalmente instável e tenta manter seu jovem mundo intacto [...] para afastar a intrusão da realidade" (VOLPE, 1967, p. 105, tradução nossa).

Quentin se veste, e sai do alojamento: “[...] Separei dois jogos de roupa de baixo, com meias, camisas, colarinhos e gravatas, e fiz a mala. [...] Tomei banho, fiz a barba. [...] Vesti o terno novo e pus o relógio no bolso" (FAULKNER, 2004, p. 77-8). O narrador prossegue:

Um pardal atravessou o raio de sol numa linha enviesada, pousou no parapeito da janela e inclinou a cabeça para mim. $\mathrm{O}$ olho era redondo e reluzente. Primeiro ele me olhava com um olho, e zás! virava o outro, a garganta latejando mais rápido que qualquer pulso. Começou a dar a hora cheia. $O$ pardal parou de trocar de olhos e ficou me observando fixamente com um olho só, até que o carrilhão parou de bater, como se também ele estivesse prestando atenção nas batidas. Então bateu asas e desapareceu (FAULKNER, 2004, p. 76, grifo nosso).

A narrativa poética, para Massaud Moisés (1967), ocorre como se "[...] o mundo de fora, o 'não eu', e o mundo de dentro, o 'eu', de repente se coordenassem num só, anulando as diferenças em favor de uma unidade bifronte, formada pelo seu intercurso" (MOISÉS, 1967, p. 29). Assim, ela estabelece a fusão entre o eu-poético e a realidade ao redor, e o narrador veicula suas percepções em material diegético permeado de componentes líricos, como no exemplo que se segue: 
A sombra ainda não havia saído por completo da varanda. Parei à porta, vendo a sombra se mover. Era um movimento quase perceptível, recuando para dentro da porta, empurrando a sombra para dentro da porta. Mas ela já estava correndo quando ouvi. No espelho ela corria antes mesmo de eu me dar conta do que estava acontecendo. Depressa com a cauda jogada sobre o braço ela saiu correndo do espelho como uma nuvem, o véu se agitando e brilhando os saltos estalando rápidos apertando o vestido contra o ombro com a outra mão, saindo do espelho os cheiros rosas rosas a voz que soava no Éden. Então ela já passava pela varanda eu não conseguia mais ouvir seus saltos ao luar como uma nuvem, a sombra do véu a flutuar pela grama, em direção aos gritos. Ela saiu do vestido correndo, segurando a grinalda, correndo em direção aos gritos [...] (FAULKNER, 2004, p. 78, itálico do autor).

No excerto destacado, Quentin sai na varanda do alojamento, e observa a sombra “[...] recuando para dentro da porta, empurrando a sombra para dentro da porta", enquanto as lembranças do casamento de Caddy manifestam-se em percepções visuais ("o véu se agitando e brilhando"); auditivas (“os saltos estalando rápido"); olfativas (“os cheiros rosas rosas”), além da mobilização de metáforas ("no espelho ela corria", "seus saltos ao luar como uma nuvem"). O encadeamento sintático possibilita a construção do ritmo imagético da narrativa, fundindose à figura feminina, onírica e esfumaçada de Caddy.

Além disso, o deslocamento da objetividade para o mundo interior de Quentin se torna visível pela utilização da tipografia em itálico, que em $O$ som e a fúria possibilita a representação das fraturas temporais (MILLGATE, 1966, p. 94-107). Assim, a tipografia convencional indica que Quentin está narrando no tempo presente, enquanto o itálico delimita as analepses, isto é, os recuos ao passado (REIS \& LOPES, 1988, p. 230-1).

A partir desse instante, inicia-se o périplo de Quentin pela cidade: o narrador toma café da manhã, leva o relógio quebrado para o conserto, e em seguida vai até uma loja de ferragens, onde compra dois ferros de passar pesados, que o ajudarão a afundar no rio (FAULKNER, 2004, p. 82). A focalização do narrador sobre a cidade determina a espacialidade, da qual Quentin retira instantes líricos, subjetivados pela recuperação memorialística do deep south:

A estrada seguia por entre as árvores, onde havia sombra, mas as folhagens em junho na Nova Inglaterra não são muito mais densas do que em abril lá no Mississippi. Vi uma chaminé. Dei as costas para ela, pisoteando a minha sombra contra a terra. [...] Eu ainda via a chaminé. Era lá que estaria a água, curativa, se espraiando em direção ao mar, às grutas tranquilas (FAULKNER, 2004, p. 108). 
No entanto, a despeito da linearidade narrativa do trecho destacado, a polifonia obsessiva na consciência de Quentin prossegue: “Um rosto reprovador lacrimoso cheiro de cânfora e de lágrimas uma voz chorando sem parar baixinho além da porta à luz do crepúsculo cheiro de madressilva com a cor do crepúsculo [...] Não encontrou a morte ao lamber o sal" (FAULKNER, 2004, p. 90, itálico do autor).

É importante ressaltar que cada fragmento de memória do narrador, articulados à composição polissêmica de sensações e imagens, equivalem ao conteúdo semântico-estrutural do verso, no sentido de não estarem encadeados de maneira convencional, por meio da pontuação. São fragmentos que instauram um ritmo e respaldam a assertiva de Freedman (1971), para quem a narrativa poética almeja a ressonância do verso: “[...] Tempo e ação podem ser simulados, mas o objetivo do poema é atingir uma intensidade específica por meio da modulação de imagens"8 (FREEDMAN, 1971, p. 7). Tal engrenagem lírica ocorre no trecho destacado: a imagética do fluxo de consciência obedece ao mecanismo da livre associação psíquica, estabelecendo um ritmo poético e visual centralizado em sua própria manifestação, isto é, no modo como irrompe à consciência do narrador.

\section{A verticalização sintática}

Para Grangeiro (2011), o monólogo de Quentin adentra um crescente processo de desagregação mental e sintática, à medida que se aproxima o momento do suicídio da personagem (2011, p. 142). Esta fragmentação, segundo a autora, realiza-se de duas formas: primeiramente, por meio da técnica da montagem narrativa que cria uma ilusão de simultaneidade dos estratos temporais, e segundo, pela ausência de pontuação que mimetiza o fluxo de pensamento (GRANGEIRO, 2011, p. 140).

Assim, em determinado instante de seu percurso pela cidade, Quentin toma um bonde a esmo, e nesse momento ocorre o ápice da fragmentação discursiva, quando o narrador revive a pulsão incestuosa pela irmã, e "[...] o texto vai perdendo o encadeamento narrativo e vai cedendo espaço para a forma de versos" (GRANGEIRO, 2011, p. 142). O trecho a seguir

\footnotetext{
8 "Time and action may be simulated, but the point of the poem's language is to reach a specific intensity by modulation of images" (FREEDMAN, 1971, p. 7).
} 
demonstra a hipótese apontada por Grangeiro, e o apresentamos integralmente, para a visualização da deformação espacial e narrativa do fluxo de consciência de Quentin:

[...] depois eu estava correndo na escuridão cinzenta cheirava a chuva e todos os cheiros de flores que o ar úmido e quente exalava e grilos serrando sem parar na grama me seguindo com uma pequena ilha móvel de silêncio Fancy do outro lado da cerca me olhava manchada como uma colcha de retalhos na corda eu pensei aquele negro desgraçado esqueceu de dar comida a ela outra vez desci a ladeira correndo naquele vácuo de grilos como um bafo se espalhando pela superfície de um espelho ela estava deitada na água a cabeça no banco de areia água fluindo em torno de suas cadeiras havia um pouco mais de luz na água a saia dela meio saturada se remexia sobre ela seguindo o movimento da água em ondas pesadas que não iam a lugar nenhum se renovavam com seu próprio movimento fiquei parado na margem sentindo o cheiro de madressilvas na água o ar parecia chuviscar madressilvas e o ruído áspero dos grilos uma substância que dava para sentir na carne

o Benjy ainda está chorando não sei está não sei coitado do Benjy sentei-me na margem a grama estava úmida um pouco então senti os sapatos molhados

sai dessa água você está maluca mas ela não se mexeu o rosto dela era um borrão branco emoldurado contra o borrão da areia pelo cabelo sai agora ela sentou-se então ficou em pé a saia batia-se contra as pernas dela escorrendo água ela subiu

a margem as roupas encharcadas sentou-se por que você não espreme as roupas quer pegar um resfriado quero

a água gorgolejava em torno do banco de areia e por cima dele no escuro entre os salgueiros no trecho raso a água se enrugava como um pedaço de pano guardando um pouco de luz como a água sempre faz ele já atravessou todos os oceanos do mundo todo então falou sobre ele agarrando os joelhos molhados o rosto inclinado para trás na luz cinzenta 
o cheiro de madressilva havia uma luz acesa no quarto da mãe e no de Benjy onde T. P. estava pondo Benjy na cama $[\ldots]$ (FAULKNER, 2004, p. 144).

No excerto destacado, o fluxo de consciência assume primeiramente o formato de monobloco, sem qualquer pontuação e disposto em uma torrente de vozes, percepções e imagens, para em seguida alinhar-se verticalmente, enquanto representa o diálogo entre Quentin e Caddy, à noite, às margens de um córrego. A organização rarefeita dos períodos realmente assemelha-se à versificação métrica, porém discordamos que as frases empilhadas submetamse à lógica estrutural do verso.

Desse modo, Quentin, apesar de sua voz lírica, não pode ser considerado um poeta, a partir da estruturação de seu discurso em versos e estrofes dispostos em uma métrica predeterminada. Tampouco pode-se pensá-lo como o criador de uma obra poética, apesar de sua inteligência e sensibilidade. Quentin é um poeta orgânico, e seu lirismo não é a consequência de uma tradição, um paideuma que o situaria em relação aos poetas do passado, do presente e do futuro (ELIOT, 1989, p. 39), mas de seu fluxo mental delirante, obsessivo e fragmentário.

$\mathrm{Na}$ realidade, o monólogo interior e fluxo de consciência de Quentin executam um movimento pendular, entre dentro e fora, objetivo e subjetivo, na representação da instabilidade psíquica do narrador. Assim, o que realmente ocorre no discurso do narrador é um processo de verticalização sintática, isto é, de deformação textual e espacial, que possibilita a representação de temas e figuras da narrativa. Nesse sentido, essa verticalização mimetiza o próprio mergulho e imersão de Quentin no rio.

Assim, com a progressão das horas desse dia, e a consequente aproximação do suicídio do narrador, a própria narrativa, em um movimento autoconsciente e metalinguístico, se deforma, e o enunciado de Quentin atinge níveis tão condensados de lembranças, vozes, desejos, imagens, além do peso subjetivo da história da família Compson, que a narrativa se fragiliza e se rompe, em um esgarçamento de sua estrutura: ela resvala da potencialidade da narrativa linear para a verticalização espacial, e opera como estratégia formal cujo papel consiste em dar sobrevida à narrativa de Quentin e à personagem. Para Bleikasten (1990), 
Reiteradamente, Quentin tenta narrar sua história de maneira ordenada; reiteradamente sua narrativa é pega no vórtex de suas obsessões. Muitos parágrafos na segunda seção iniciam-se bem convencionais como narração controlada, apenas para terminarem em um errático discurso interior. [...] Quanto mais se aproxima seu clímax emocional (o encontro decisivo de Quentin e Caddy no bosque), menos Quentin domina sua linguagem; quanto mais ele adentra seu monólogo, menos ele fala e mais ouve as míriades de vozes do passado 9 (BLEIKASTEN, 1990, p. 73, grifo do autor, tradução nossa).

Desse modo, partindo das premissas de Rosenfeld (2006), a narrativa de Quentin desrealiza-se, já que na progressão gradual do romance, e à medida que o dia desloca-se sobre o eixo da temporalidade, as instâncias de tempo, espaço e linguagem vão se tornando cada vez mais esboroadas, atingindo instantes de completa desagregação linguística e luminosidade poética (ROSENFELD, 2006, p. 76). Para Auerbach (2002), “[...] a consciência do caráter [...] descontínuo da realidade moderna [...] da sequência desordenada do tempo, invade o romance modernista” (AUERBACH, 2002, p. 336).

No plano semântico, há no trecho apontado indicações espaciais ("grama", "margem", "banco de areia") e temporais, já que "escuridão cinzenta" remete à noite. Segundo Chevalier \& Gheerbrant, “[...] entrar na noite é entrar no indeterminado [...]. Ela é a imagem do inconsciente" (CHEVALIER \& GHEERBRANT, 1997, p. 640). Instaura-se, nesse momento da narrativa, uma atmosfera de abundância, excesso e fertilidade, pautada em imagens noturnas de umidade ("escuridão cinzenta", "cheirando à chuva", "cheiros de flores", “ar úmido e quente"), que remete aos fluidos corpóreos, ao desejo, à sexualidade.

Além disso, Quentin está parado na margem do riacho, enquanto Caddy encontra-se deitada neste. A fusão da água com a terra forma a lama ou argila. Para Chevalier \& Gheerbrant (1997), a lama significa tanto o princípio criador em seus primórdios, quanto “[...] um processo involutivo, um início de degradação [...] água contaminada, corrompida" (CHEVALIER \& GHEERBRANT, 1997, p. 534). Já para Bachelard, “A união da água e da terra dá a massa. A massa é um dos esquemas fundamentais do materialismo. [...] Com efeito, a massa nos parece

\footnotetext{
9 “Again and again Quentin attempts to tell his story in orderly fashion; again and again his narrative gets caught in the vortex of his obsessions. Many paragraphs in the second section begin quite conventionally as controlled narration, only to end in erratic interior discourse. The closer one gets to its emotional climax (Quentin's decisive encounter with Caddy at the branch), the less Quentin master his language; the deeper he moves into his monologue, the less he speaks and the more he listens to the myriad voices of the past" (BLEIKASTEN, 1990, p. 89 , grifo do autor).
} 
ser o esquema do materialismo realmente íntimo em que a forma é excluída, apagada, dissolvida [...]" (BACHELARD, 1997, p. 109).

Assim, a lama primária na qual Quentin e Caddy estão assentados remete ao incesto imaginário idealizado por Quentin, e à culpa advinda dele. Como um Adão e Eva primordiais, expulsos da "[...] reprovação e o horror além da chama limpa" (FAULKNER, 2004, p. 112), a lama também remete ao próprio aspecto amorfo da narrativa, do ponto de vista da sintaxe convencional.

Ainda segundo Jean-Yves Tadié (1978), “A descrição do espaço poético [é] aberto aos símbolos" (TADIÉ, 1978, p. 36). De fato, no trecho destacado, a geografia disfórica do riacho circunscreve uma isotopia da morte calcada em imagens polissêmicas ("vala", "ossos", "urzes escuras", “cicatriz negra”), na qual Quentin e Caddy fazem um pacto de assassinato mútuo, enquanto a estrutura do fluxo de consciência do narrador definha ainda mais:

[...] levei a ponta da lâmina até a garganta dela é coisa de um segundo só um segundo depois eu faço na minha eu faço na minha depois

está bem você consegue fazer na sua sozinho claro a lâmina é bem comprida o Benjy já está deitado

está bem

é coisa de um segundo só isso vou tentar fazer de um jeito que não doa está bem fecha os olhos por favor assim não vai ter que enfiar com mais força ponha a sua mão mas ela não se mexia os olhos estavam bem abertos olhando para o céu por cima da minha cabeça

(FAULKNER, 2004, p. 147).

Assim, julgamos que a atmosfera noturna, úmida e pulsional do riacho remete ao desejo sexual de Quentin por Caddy, pela instauração de um espaço que metaforiza a sexualidade e a fertilidade; e de outro lado, articula-se às pulsões de morte dispostas nas materialidades 
isotópicas do lugar. Tal isotopia poética auxilia no processo de deformação sintática da narrativa, que verticalmente escorre como o sêmen de Quentin ou as secreções sexuais do hímen de Caddy, que o irmão deseja possuir, mas não pode porque "[...] havia uma coisa terrível em mim às vezes à noite eu via a coisa sorrindo para mim eu via através deles sorrindo para mim [...] a que sorri pra você a coisa através deles" (FAULKNER, 2004, p. 108, grifo nosso).

\section{Lonicera periclymenum}

Na consciência de Quentin, o perfume da flor de madressilva opera como símbolo dos desejos incestuosos experimentados em relação à irmã (BLEIKASTEN, 1990):

[...] o peito dela úmido e duro eu ouvia seu coração batendo firme e lento agora não martelando e a água gorgolejando entre os salgueiros no escuro e ondas de madressilva subindo no ar meu braço e meu ombro estavam retorcidos sob meu corpo [...] (FAULKNER, 2004, p. 147).

A madressilva (honeysuckle), planta da família das Caprifoliaceae, de nome científico Lonicera Periclymenum, possui flores de perfume adocicado e agrega-se em arbustos e sebes, em um emaranhado de folhas, galhos e flores do qual despontam pequeninas flores amarelas e delgadas. Dotada de folhas lanosas e verde-escuras, a madressilva remete, em sua forma delgada, a um cálice comprido voltado para cima, de onde partem as pétalas, inicialmente brancas, mas que tornam-se amarelas com o tempo, além dos estames, que saltam para fora do cálice.

Como a estrutura do pensamento de Quentin, a corola da flor de madressilva é rarefeita e fragmentada, quase apenas forma, com seus estames eretos e exuberantes, espalhando sua fragrância intrusiva pelas sebes e pela consciência do personagem. Esse caráter parasita e opressor do perfume é ressaltado constantemente pelo narrador, e o aspecto fantasmagórico da madressilva opera como metáfora para relação sexual imaginária dos irmãos, a partir da 
estrutura da flor, formada pelo androceu (masculino) e o gineceu, (feminino). Para Volpe (1967),

\begin{abstract}
A madressilva não é simplesmente um símbolo do desejo incestuoso de Quentin; é um símbolo do sexo, da maturidade sexual dele e de Caddy. É um odor penetrante do qual Quentin não pode escapar, assim como ele não pode escapar da perda de sua relação de infância com Caddy. O sexo ameaça o mundo que Quentin deve preservar. Uma análise detalhada da cena no riacho mostra que o único desejo de Quentin é manter seu mundo isolado intacto, negando a realidade do ato de Caddy ${ }^{10}$ (VOLPE, 1967, p. 112, tradução nossa).
\end{abstract}

\title{
O retorno
}

O dia prossegue, e Quentin envolve-se em uma confusão com uma garota imigrante que passa a segui-lo, e o incidente termina na delegacia. Depois de encontrar com amigos de faculdade que o ajudam, o narrador está finalmente pronto para o instante final. Como sua própria linguagem desagregada e poética, Quentin diz: “À medida que eu ia descendo, a luz diminuía pouco a pouco, mas sem mudar de qualidade, como se eu, e não a luz, é que estivesse mudando, diminuindo" (FAULKNER, 2004, p. 163). Na janela do bonde, sob o entardecer, sua voz assume a materialidade incandescente da substância poética:

Foi aqui que vi o rio pela última vez nesta manhã, mais ou menos aqui. Eu sentia a presença da água além do crepúsculo, o cheiro. Quando as flores se abriam na primavera e chovia o cheiro estava em toda parte a gente não reparava nele muito em outras ocasiões mas quando chovia o cheiro começava a entrar na casa à hora do entardecer ou chovia mais ao entardecer ou então havia alguma coisa na luz em si mas era sempre nessa hora que o cheiro era mais forte até que eu me deitava na cama pensando quando será que vai parar quando será que vai parar (FAULKNER, 2004, p. 165).

De acordo com Tadié (1978), a narrativa poética pauta-se na “[...] utilização dos poderes da repetição", a partir da imagem do "[...] círculo, da estrutura circular" (TADIÉ, 1978, p. 4). A jornada lírica de Quentin em direção à morte cumpre seu final: o narrador retorna a seu

\footnotetext{
10 "Honeysuckle is not simply a symbol of Quentin's incestuous desire; it is a symbol of sex, of his and Caddy's sexual maturity. It is a pervasive odor from which Quentin cannot escape, just as he cannot escape the loss of his childhood relationship with Caddy. Sex threatens the world that Quentin must preserve. A close analysis of the scene at the creek shows that Quentin's sole desire is to keep his insulated world intact by denying the reality of Caddy's act" (VOLPE, 1967, p. 112).
} 
quarto, e finaliza a narrativa do mesmo modo como a iniciou, cumprindo um ritual circular. A fragmentação da linguagem continua, em imagens oníricas, análogas às alucinações hipnagógicas do estado de vigília: "[...] e no entanto sem ver apertados como dentes não desacreditando duvidando até mesmo a ausência de dor canela tornozelo o longo fluxo invisível do corrimão da escada onde um passo falso na escuridão cheia de sono [...] (FAULKNER, 2004, p. 168, itálico do autor). Neste ponto, Quentin atingiu o ápice da desagregação sintática e pode desaparecer, como sua linguagem.

\section{REFERÊNCIAS}

AUERBACH, Eric. A meia marrom. In: AUERBACH, Eric. Mimesis: a representação da realidade na literatura ocidental. 4. ed. São Paulo: Perspectiva, 2002. p. 471-498.

AZEVEDO, Carlos. Do modernismo em William Faulkner: As I lay dying. In: AMARAL, Ana Luísa; CUNHA, Gualter (Org.). Estudos em homenagem a Margarida Llosa. Porto: Faculdade de Letras da Universidade do Porto, 2006. p. 71-97.

BACHELARD, Gaston. A poética do espaço. Tradução de Antonio de Pádua Danesi. São Paulo: Martins Fontes, 1993.

BACHELARD, Gaston. A água e os sonhos: ensaio sobre a imaginação da matéria. Tradução de Antonio de Pádua Danesi. São Paulo: Martins Fontes, 1997.

BLEIKASTEN, André. The ink of melancholy. Bloomington: Indiana University Press, 1990.

BROOKS, Cleanth. Man, Time and Eternity. In: BROOKS, Cleanth. The Yoknapatawpha Country. Estados Unidos: Lousiana Paper Back Edition, 1990. p. 325-348.

CHEVALIER, Jean; GHEERBRANT, Alain. Dicionário de símbolos (mitos, sonhos, costumes, gestos, formas, figuras, cores, números). Tradução de Vera da Costa e Silva. 11. ed. Rio de Janeiro: José Olympio, 1997.

ELIOT, T. S. Obra completa: v. I - Poesia. Tradução, introdução e notas de Ivan Junqueira. São Paulo: Arx, 2004.

FAULKNER, William. O som e a fúria. Tradução de Paulo Henriques Britto. São Paulo: Cosac \& Naify, 2004.

FREEDMAN, Ralph. The lyrical novel: studies in Herman Hesse, Andre Gide and Virginia Woolf. Princeton University Press, 1971. p. 1-18.

GENETTE, Gérard. Discurso da narrativa. Tradução de Fernando Cabral Martins. Lisboa: Vega Universidade, 1979.

GRANGEIRO, Alessandra Costa. Tempo e Memória na obra de William Faulkner. 240f. Tese (Doutorado em Estudos Literários) PPGLL/UFG. Faculdade de Letras. Goiânia, 2011.

MILLGATE, Michael. The Sound and The Fury. In: WARREN, R. P. (Org). Faulkner: a collection of critical essays. New Jersey: A Spectrum Book, 1966. p. 94-108. 
MOISÉS, Massaud. A prosa poética. In: MOISÉS, Massaud. A criação literária. Prosa II. São Paulo: Cultrix, 1967. p. 19-68.

OLIVEIRA, Itamar Aparecido. Mitos e arquétipos em O som e a fúria, de William Faulkner: ensaios. 150f. Dissertação (Mestrado em Literatura). PPG de Literatura e Crítica Literária. PUC São Paulo, SP, Brasil, 2015.

REIS, Carlos; LOPES, Ana Cristina M. Dicionário de teoria da narrativa. São Paulo: Editora Ática, 1988.

ROSENFELD, Anatol. Reflexões sobre o romance moderno. In: ROSENFELD, Anatol. Texto e contexto I. São Paulo: Perspectiva, 2006, p. 75-97.

STEIN, Jean. William Faulkner: a arte da ficção 12. In: As entrevistas da Paris Review. v. 1. Tradução de Christian Schwartz e Sérgio Alcides. São Paulo: Companhia das Letras, 2011.

TADIÉ, Jean-Yves. Le récit poétique. Paris: PUF, 1978.

VOLPE, Edmond. A reader's guide to William Faulkner. New York: Farrar, Straux and Giroux, 1967. 